\author{
Kamil Liberadzki ${ }^{1}$ \\ Marcin Liberadzki ${ }^{2}$
}

\title{
EUROPE 2020 PROJECT BONDS INITIATIVE PILOT PHASE
}

\section{Summary}

Private sector financing of transport infrastructure in Europe still falls behind pre-crisis levels. Budgetary constraints in the public sector for infrastructure financing together with banks unable to deliver the volume of debt needed for infrastructure financing create need for alternative sources of funding from capital markets.

Infrastructure financing is mostly debt financing. Use of high leverage (project financing) explains the investment characteristics of the infrastructure. The aim of the European Commission's 2020 Project Bond Initiative (PBI) is to encourage investments in infrastructure projects by institutional investors. Bond financings for public private partnership (PPP) projects and other project financings for infrastructure in Europe effectively ended with the demise of several monolines in the early stages of the credit crunch. The PBI is designed to facilitate institutional investor appetite for projects by offering credit enhancement from the EIB, and with the EIB acting as controlling creditor. The initiative proposes two forms of credit enhancement: a fully-funded subordinate tranche equal to up to $20 \%$ of the senior debt and a guarantee of senior debt of up to $20 \%$. Subordinated debt tranche by the European Investment Bank (EIB) provides cushion for senior debt service. PBI helps support standardization and widening of investor market. In addition to competitive pricing, EIB also adds value given its reputation and track record in screening, mitigating and monitoring project risk.

\footnotetext{
1 dr Kamil Liberadzki - Zakład Finansów Przedsiębiorstwa, Instytut Finansów, Kolegium Zarządzania i Finansów, Szkoła Główna Handlowa w Warszawie, e-mail: Kamil.Liberadzki@sgh. waw.pl.

dr Marcin Liberadzki - Zakład Finansów Przedsiębiorstwa, Instytut Finansów, Kolegium Zarządzania i Finansów, Szkoła Główna Handlowa w Warszawie, e-mail: Marcin.Liberadzki@sgh.waw.pl.
} 
As Basel III bites - the first wave of bank compliance is set for 2015, with fullcompliance due in 2018 - the cost of long-term bank debt should make bond solutions comparatively affordable. As project infrastructure is a specialized asset class and new to many investors, PBI has a vital role to play in supporting institutional investment. The A11 motorway project in Belgium, Spain's Castor energy storage plant and the UK's Greater Gabbard offshore transmission link are three projects to receive credit enhancement under the pilot phase of the EIB's 2020 scheme.

Keywords: Project bonds, public-private partnerships, infrastructure financing, European Investment Bank, credit enhancement

\section{Preface}

Europe faces higher infrastructure investment needs than in the recent past in transport, energy and ICT networks in this decade, totaling several trillion euros, to meet the policy goals of the Europe 2020 strategy and to maintain or upgrade existing infrastructure. According to the Commission's estimates transport and energy infrastructure require investments of EUR 700 billion for the highest priority projects. At a conference on the European 2020 Project Bond Initiative in Brussels in April 2011, Olli Rehn, the European commissioner for economic and monetary affairs said: "Partly due to the fall in investment during the crisis, estimates on investment volumes considered necessary in Europe's transport, energy and communication networks until 2020 point to total amounts between EUR 1.5 and EUR 2 trillion. However, currently our public budgets are struggling with the necessary fiscal consolidation. That's why we need to find smart ways and means to fund projects of major public interest." 3

Suggesting that around EUR 500 billion will have to be invested to create 'a real European network' by 2050 as envisaged in the recent transport white paper, the Commission has grouped the most important projects into 10 crossborder corridors to be developed by 2030. The Core Network has emerged from a review of the Trans-European Transport Network (TEN-T) TEN-T programme, and will be supported by other feeder routes at regional and national level, which are to be financed largely by member states with some EU support. ${ }^{4}$ nance, 2011.

3 P. Smith, Engineering the EIB bond guarantee, Project Finance \& Infrastructure Fi-

4 EU plan builds on TEN-T revisions, Railway Gazette International, 2011, Vol. 167, Issue 11, p. 26. 
The Tables 1. do not constitute a funding gap, but represent the total investment requirements, whether publicly or privately financed or addressed by policy in these sectors. ${ }^{5}$

In Poland, substantial capital expenditure is required to improve the features of rail and road infrastructure to match those of the developed countries: ca. PLN 13 billion a year for railway infrastructure and PLN 19 billion for road infrastructure, to be invested for at least the next fifteen years.

Table 1.

Financial needs for transport infrastructure development in Poland

\begin{tabular}{|c|c|c|}
\hline Funding requirement (per annum) & Road Infrastructure & Railway Infrastructure \\
\hline expansion/modernization & PLN 15 billion & PLN 10 billion \\
\hline rehabilitation and maintenance & PLN 4 billion & PLN 3 billion \\
\hline Total & PLN 19 billion & PLN 13 billion \\
\hline
\end{tabular}

Source: J. Pieregud, Analysis of road and railway infrastructure needs for 2014-2020, in: A. Cholewa, K. Liberadzki, M. Liberadzki, K. Piech, J. Pieregud, How to finance effectively the development of transport infrastructure in Poland in the financial perspective 2014-2020, House of Solutions International, Warsaw 2013, p. 36.

Based on those assumptions, the funding requirements have been estimated for construction, modernization and maintenance of the road infrastructure in the years 2014-2020 at ca. PLN 132 billion and for the rail infrastructure at ca. PLN 90 billion. This translates into the annual requirement of PLN 32 billion. ${ }^{6}$

This means that the financial gap between the requirement with respect to investments in road and rail infrastructural projects and the funds that will be available for that purpose under the new perspective 2014-2020 is, for road infrastructure, ca. PLN 67 billion and for rail infrastructure PLN 46 billion. The funding requirement in this respect largely exceeds the public funding capabilities (both Polish and EU) and makes the involvement of the private sector necessary. ${ }^{7}$ Commercial provision of transport infrastructure may effect in revenues for private investors with important public benefits.

5 A pilot for the Europe 2020 Project Bond Initiative COM, Brussels (2011) 660.

6 J. Pieregud, Analysis of road and railway infrastructure needs for 2014-2020, in: A. Cholewa, K. Liberadzki, M. Liberadzki, K. Piech, J. Pieregud, How to finance effectively the development of transport infrastructure in Poland in the financial perspective 2014-2020, House of Solutions International, Warsaw 2013.

7 Ibidem. 


\section{PPPs}

Involvement of private sector into provision and operation of infrastructure under a public-private partnership (PPP) scheme represents an investment challenge because they involve large and sunk capital investments that have limited value as collateral and are subject to a wide range of commercial and non-commercial risks, including traffic, regulatory, fx 8 and political risks.

PPPs are typically financed with equity from sponsors or other investors and bank loans. Debt represents major part of funding sources, up to $80 \%$ of the project value. The Table 2. presents gives an idea of how the motorway projects are leveraged.

\section{Table 2.}

The sources of finance structure for the selected motorway projects

\begin{tabular}{|l|c|}
\hline \multicolumn{1}{|c|}{ Country, project } & Equity/debt \\
\hline China, Guangzhou-Shenzhen Superhighway & $58: 42^{*}$ \\
\hline Colombia, Buga-Tuluá Highway & $51: 49^{*}$ \\
\hline Chile, South Access to Concepción & $41: 59^{*}$ \\
\hline Poland, A-2: Nowy Tomyśl-Poznań-Konin & $29: 71^{*}$ \\
\hline Ireland, Limerick Tunnel & $23,2: 76,8^{*}$ \\
\hline Hungary, M1/M15 & $20: 80^{*}$ \\
\hline Finland, E18 & $20: 80$ \\
\hline USA, SR-91 & $15: 85^{*}$ \\
\hline Slovakia, R1 & $13,2: 86,8$ \\
\hline Austria, A5 & $12: 88$ \\
\hline Poland, A-2: Świecko-Nowy Tomyśl & $12: 88$ \\
\hline
\end{tabular}

"Equity includes subordinated loans. The capital structure on financial close.

Source: Meridiam Infrastructure data and authors' own calculations based on: G. Fisher, S. Babbar, Private Financing of Toll Roads, RMC Discussion Paper Series 117, pp. 33-34.

Infrastructure projects typically require very long-term financing, something that is not widely on offer presently. As banks face balance sheet and maturity constraints for a number of reasons including higher funding costs, higher capital requirements and a continuing need to provision for losses, the potential role of bond markets increases. The Europe 2020 Project Bond Initiative contemplates the credit enhancement of senior secured project bonds to achieve a robust level of

8 The project is exposed to exchange rate risk since debt is usually denominated in foreign currency while revenues are in local currency. 
credit quality - potentially in the single-A rating range - that would be attractive to institutional investors. Credit enhancement may take the form of either funded subordinated debt, or an unfunded partial guarantee of senior debt service. The European Commission's outline proposals, if implemented appropriately, would be capable of credit-enhancing senior secured project bonds issued by PPP projects from low investment-grade to single-A ratings.

\section{Project Bond Initiative}

Privately financed infrastructure projects in Europe rely heavily on bank lending, which is not readily available at maturities reflecting the long-term life cycle of an infrastructure project. Basel III's higher capital requirements continue to curtail western banks' readiness to provide long-term funding.

Major efforts are needed to facilitate infrastructure projects' access to private finance and to develop alternative ways of debt financing for them. ${ }^{9}$ In order to improve projects' access to financing and develop a vibrant infrastructure bond market, where private initiatives have made little progress so far, the EU intends to cooperate with the EIB in order to create a facility to support the private issuance of project bonds, the Europe 2020 Project Bond Initiative. 50 billion euro spending plan to improve Europe's transport, energy and digital networks The Europe 2020 Project Bond Initiative (PBI) is the joint program by the European Commission and the EIB unveiled on October 19, 2011. ${ }^{10}$ It is noted that 31.7 billion euros will be provided by the transport element of the Connecting Europe Facility to upgrade infrastructure. Rail and port expansion projects lie at the heart of a €50bn spending plan to improve Europe's transport, energy and digital networks unveiled by the European Commission on October 19. This will form a key element in the EU budget for 2014-2020. ${ }^{11}$

The PBI employs standard structuring techniques to divide the project debt into a senior tranche and a subordinated tranche, which is in turn senior to equity. The credit enhancement is likely to take the form of either of a first loss piece or

9 A pilot for the Europe 2020 Project Bond Initiative, Brussels COM (2011) 660.

10 Regulation No. 670/2012 of the European Parliament and of the Council of 11 July 2012 amending Decision No. 1639/2006/EC establishing a Competitiveness and Innovation Framework Programme (2007-2013), OJ L 204/1, 31/07/2012. See also: Europe 2020 - A strategy for smart, sustainable and inclusive growth, COM (2010) 2020 final.

11 EU plan builds on TEN-T revisions, Railway Gazette International, 2011, Vol. 167, Issue 11, p. 26. 
a type of contingent credit line, which would also become subordinated debt if drawn. The aim is to lift the credit rating of a project to the A or AA rating needed to attract large numbers of institutional investors.

How sponsors and grantors flesh out the concept will depend in part on whether they decide to use the unfunded or funded credit enhancement from the EIB. Both the EIB's funded and unfunded credit enhancements will be available during the entire life of the project and will be used to cover capital expenditure during the construction phase and ensure adequate debt service coverage. The difference between the two options is most obvious during the construction phase. Whereas the first loss piece would be factored in the base case model, the contingent facility would not and could be drawn to meet cost overruns during the construction phase, provided that the technical adviser could certify that construction completion would take place before the long stop date. On the other hand, if the unfunded credit enhancement is drawn during the construction phase, it would be limited to repaying debt during operations. ${ }^{12}$

The use of the unfunded credit enhancement during the operational phase is likely to depend on a debt service coverage ratio test, so that if the Debt Service Cover Ratio (DSCR) falls below a predetermined level, the credit enhancement would be drawn. ${ }^{13}$ Subordinated debt could be also granted as a result of the occurrence of unpredicted events, such as lower than originally expected traffic volume on the toll road during the operation phase. The subordinated tranche could also be subscribed for as a bond of an appropriately lower rating.

The major instrument to support the transportation infrastructure project, recommended by the European Commission, is to be the so-called project bonds. Such bonds constitute senior debt. For project companies that are seeking to raise senior debt by issuing project bonds, the EIB would provide a credit enhancement for up to $20 \%$ of the senior debt, which should, in theory, allow pension funds to participate at sponsor-friendly yields.

The Figure 1. provides for the financing options on the Euromarkets. During the bond issue process a separate special purpose vehicle is established (labeled SPV in the figure - Eurobond issuer) whose task is purely technical: to receive funds from the buyers of the project Eurobonds and deposit such funds to the concessionaire's account, the latter being the end beneficiary. Based on, for example,

12 Agreement - but little clarity - on EU-EIB project bond pilot, Project Finance \& Infrastructure Finance, 2012, p. 75.

13 Ibidem. 
a CDA (Cash Deposit Agreement) contract, the debt interests and capital repayment are assumed by the "original issuer." A similar effect may be achieved using other techniques, for example the mirror bonds. If the EIB support could be inserted into the project, the bonds would gain the status of Project Eurobonds and would most likely permit obtaining a higher rating. ${ }^{14}$

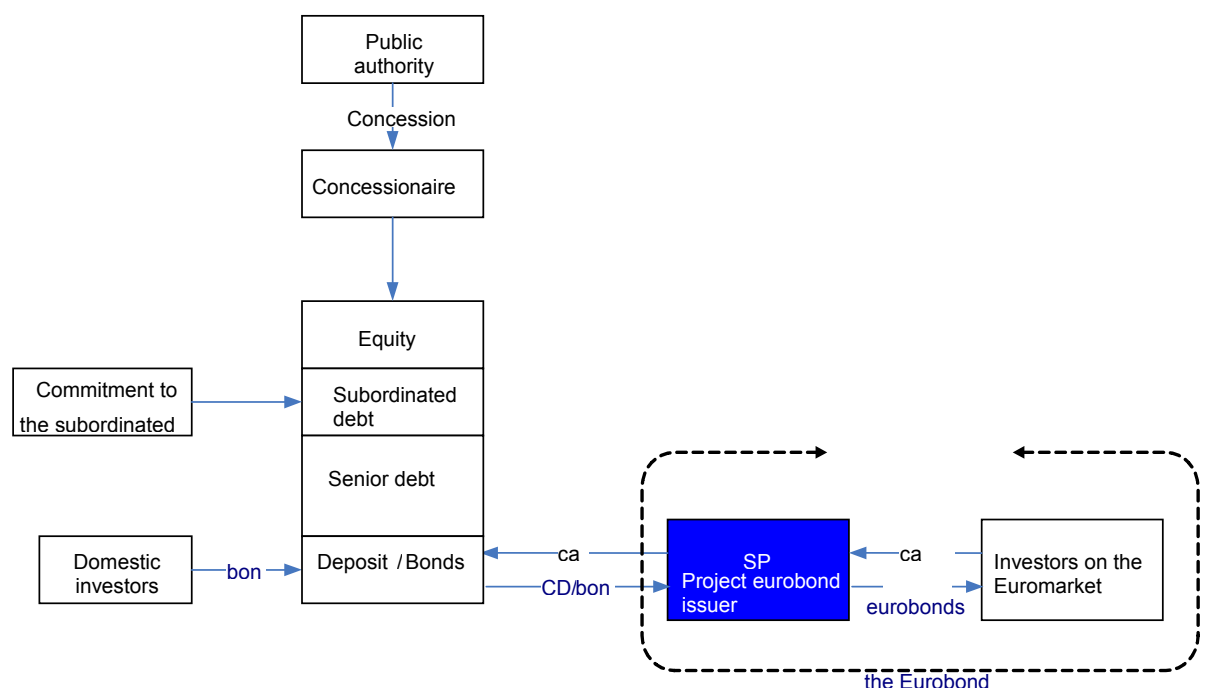

Figure 1. Project bonds issue scheme

Source: K. Liberadzki, M. Liberadzki in: A. Cholewa, K. Liberadzki, M. Liberadzki, K. Piech, J. Pieregud, How to finance effectively the development of transport infrastructure in Poland in the financial perspective 2014-2020, House of Solutions International, Warsaw 2013.

The collapse of the monoline bond insurers, which halted the development of a liquid European project bond market, is one of the inspirations for the initiative. But the initiative is different to the monoline model, since it is only meant to enhance bonds to the AA or AA-level, and the total support from the EIB, which will be implementing the initiative, is capped from the outset. ${ }^{15}$ While the products are designed to fill the void left by the disappearance of the monolines, they would not involve wrapping the entire debt amount to AAA.

14 K. Liberadzki, M. Liberadzki in: A. Cholewa, K. Liberadzki, M. Liberadzki, K. Piech, J. Pieregud, How to finance effectively the development of transport infrastructure in Poland in the financial perspective 2014-2020, House of Solutions International, Warsaw 2013.

15 Agreement-but... 
In a special comment on the initiative, ratings agency Moody's says that both forms of credit enhancement are capable of lifting "senior secured project bonds issued by PFI/PPP projects from low investment-grade to single-A ratings." 16

\section{EIB Project Bond Pilot}

The PBI is in a pilot phase at the moment, under which the EC has provided EUR 230 million of financing from existing budgets to promote Trans-European Networks projects in transport, energy and communications.

The EIB will deploy this money as capital, with the Commission taking most of the first loss risk up to that EUR 230 million limit. Thereafter, risk lies with the EIB. The European Commission and EIB in 2012 agreed and legislated for a scheme under which the EIB can credit-enhance projects financed in the bond market. ${ }^{17}$

The EU and EIB have pledged initially (end of 2012) to invest EUR 230 million during the pilot phase, expecting to provide a multiplier of effect of roughly $29 \mathrm{x}$ and as such to stimulate Eu4.4 billion of capital markets issuance. The new initiative is targeted towards priority projects in the transport (TEN-T), energy (TEN-E) and broadband sectors. ${ }^{18}$ The EIB has supported the issue of a EUR 1.4 billion bond for the Castor gas storage facility. The PBI also supported the issue of a GBP305 million bond for the Greater Gabbard OFTO project in the UK, which involves the electricity transmission assets linking 500MW of offshore wind farms to the UK onshore grid. These two transactions are followed by the A11 motorway project in Belgium.

\section{The Castor Project}

Using capital provided by the European Commission, the EIB gave $€ 200$ million of credit enhancement to a $€ 1.4$ billion bond that refinances the Castor Project to store gas underground off the Spanish coast (Table 3.).

16 P. Smith, Engineering the EIB...

17 EIB cracks project bond conundrum with Castor deal, Euroweek, 7/30/2013, Issue 1315, p. 84.

18 Agreement-but... 
Table 3.

Project overview

\begin{tabular}{|c|c|}
\hline Project & $\begin{array}{l}\text { - The Castor Project concerns the construction and operation of an } \\
\text { off-shore underground gas storage facility }\end{array}$ \\
\hline Status & $\begin{array}{l}\text { - Construction completed } \\
\text { - Awaiting full inclusion in the Spanish gas system }\end{array}$ \\
\hline Project Details & $\begin{array}{l}\text { - No use of EU budget in the financing of the project } \\
\text { - EUR } 200 \mathrm{M} \text { PBCE - project rating of } \mathrm{BBB}+, \mathrm{BBB} \\
\text { - } \text { All-in fixed coupon } 5.756 \% \\
\end{array}$ \\
\hline Concession Grantor & - Spanish Ministry of Industry, Energy and Tourism \\
\hline Concession Term & - 30 years, extendable to 50 years by 2 periods of 10 years \\
\hline Location & $\begin{array}{l}\text { The former Amposta (Castellón) oil reservoir that was exploited by } \\
\text { Shell in the } 1970 \mathrm{~s} \text { and } 80 \mathrm{~s} \text {, situated } 21 \mathrm{~km} \text { offshore from the coast } \\
\text { of Vinaroz }\end{array}$ \\
\hline $\begin{array}{l}\text { Essential Infrastructure } \\
\text { for the Spanish Gas and } \\
\text { Electricity Sectors }\end{array}$ & $\begin{array}{l}\text { - One of three gas storage facilities in Spain. } \\
\text { Modulates and adjusts the supply and demand of the Spanish Gas } \\
\text { System by ensuring storage of minimum stock to guarantee the } \\
\text { continuity of System's gas supply. } \\
\text { This strategic reserve was classified as Type Urgent by the Co- } \\
\text { uncil of Ministers in the 2008-2016 Electricity and Gas Sector } \\
\text { Planning report; this entails the highest level of priority for the } \\
\text { Spanish Gas System }\end{array}$ \\
\hline
\end{tabular}

Source: Project Bond pilot phase. EP - TRAN Committee, 18 March 2014.

The Castor project has involved building facilities so that an empty oilfield under the Mediterranean seabed off Valencia can be used to store natural gas, to improve security of supply to the Spanish network. Spanish construction firm ACS is the lead party in the project consortium, which has a 30 year concession from 2008, extendible for two 10 year periods. The project was completed on time and within budget, and is going through final acceptance procedures before being declared ready for use. The original bank debt is being refinanced with the bond. Debt is about $80 \%$ of the project's capital, equity $20 \%$. Standard \& Poor's believes it will be able to run at a minimum debt service coverage ratio of $1.26 .{ }^{19}$

\section{The A11 Highway}

After UK's Greater Gabbard offshore transmission link the third project to receive credit enhancement under the pilot phase of the EIB's 2020 scheme is the A11 highway PPP. The project concerns a motorway connection between Bruges

$19 \quad$ EIB cracks project... 
and Knokke in the Belgian province of West Flanders. The A11 is the first transport TEN-T Project and first greenfield project to be financed through PBI.

The A11 project company is funded by equity injections by both Via Brugge and public sector agency Via-Invest, the EIB' $€ 115$ million subordinated credit facility (which provides the credit enhancement), and $€ 578$ million or project bonds. The credit enhancement received a three notches uplift to A3 (by Moody's).

As the first 2020 greenfield project, the deal sets a precedent for the cost overrun mechanic to be used in EIB-supported deals. The credit enhancement letter of credit should be available as a back-up. This mechanism is likely to be applied to future 2020 greenfield deals. ${ }^{20}$

\section{Closing Remarks}

The PBI pilot phase commenced end of 2012 and allows project approval by the EIB Board until the end of 2014 and financial close until the end of 2016. ${ }^{21}$

According to the EC's and EBI's estimates, Total of EUR 1,220 million of potential project bond credit enhancements are identified at the end of 2013 for pilot phase. With facilities representing $20 \%$ of the senior debt to be raised through a capital market instrument, the total potential project bond issues amount to EUR 6,100 million - EUR 12,200 million. If the bond is $90 \%$ of the total project costs, this represents total potential project costs of approximately EUR 6,800 million $-13,550$ million. $^{22}$

So far eight projects have been approved by the EIB Board as potential beneficiaries of project bond credit enhancement and further projects are being advanced. Three projects have been credit enhanced by EIB. One of these three projects was closed without support from the EU budget. ${ }^{23}$

20 D. Myles, A11 proves governments will back project bonds, "International Financial Law Review", 2014, Vol. 33, Issue 6, p. 121.

${ }^{21}$ Interim report on the pilot phase of the Europe 2020 Project Bond Initiative, Brussels, COM (2013) 929.

22 Project Bond pilot phase, EP - TRAN Committee, 18 March 2014.

23 Interim report... 


\section{References}

Agreement - but little clarity - on EU-EIB project bond pilot, Project Finance \& Infrastructure Finance 2012.

Cholewa, A., Liberadzki, K., Liberadzki, M., Piech, K., Pieregud, J., How to finance effectively the development of transport infrastructure in Poland in the financial perspective 2014-2020, House of Solutions International, Warsaw 2013.

EIB cracks project bond conundrum with Castor deal, Euroweek. 7/30/2013, Issue 1315.

EU plan builds on TEN-T revisions, "Railway Gazette International” 2011, Vol. 167 Issue 11.

Fisher, G., Babbar, S., Private Financing of Toll Roads, RMC Discussion Paper Series 117.

Myles, D., A11 proves governments will back project bonds, "International financial Law Review" 2014, Vol. 33, Issue 6.

Smith, P., Engineering the EIB bond guarantee, Project Finance \& Infrastructure Finance 2011 .

\section{Documents}

A pilot for the Europe 2020 Project Bond Initiative, Brussels, COM (2011) 660.

Europe 2020 - A strategy for smart, sustainable and inclusive growth, Brussels, COM (2010) 2020 final.

Interim report on the pilot phase of the Europe 2020 Project Bond Initiative, Brussels, COM (2013) 929.

Project Bond pilot phase, EP - TRAN Committee, 18 March 2014.

Regulation No. 670/2012 of the European Parliament and of the Council of 11 July 2012 amending Decision No 1639/2006/EC establishing a Competitiveness and Innovation Framework Programme (2007-2013), OJ L 204/1, 31/07/2012.

\section{PILOTAŻOWA FAZA EUROPE 2020 PROJECT BONDS INITIATIVE}

\section{Streszczenie}

Ocena potrzeb w zakresie budowy, modernizacji i utrzymania infrastruktury transportowej w Unii Europejskiej w nowej perspektywie finansowej 2014-2020 w odniesieniu do rzeczywistych możliwości budżetów zarówno krajów członkowskich, jak i samej Unii 
Europejskiej prowadzi do wniosku, że powstanie luka finansowa między potrzebami w zakresie finansowania projektów transportowych a środkami, które będą dostępne na ten cel w nowej perspektywie 2014-2020. Komercjalizacja budowy i eksploatacji obiektów infrastruktury transportu w ramach publiczno-prywatnego partnerstwa (PPP) może być jedynym rozwiązaniem w sytuacji ograniczonych środków budżetowych. Pozyskanie finansowania na rynku długu dla projektów infrastruktury transportowej realizowanych w ramach PPP wymaga wsparcia kredytowego tych przedsięwzięć. Komisja Europejska wraz z Europejskim Bankiem Inwestycyjnym (EBI) stworzyła mechanizmy wsparcia kredytowego projektów poprzez obejmowanie transz podporządkowanych długowi w ramach inicjatywy obligacji projektowych (2020 Project Bond Initiative - PBI). Obecnie realizowany jest etap pilotażowy tej inicjatywy. EBI wspiera w ramach PBI trzy projekty, z których dwa są omówione w niniejszym artykule: refinansowanie budowy zbiorników gazu u wybrzeża Hiszpanii (projekt Castor) oraz finansowanie budowy autostrady płatnej A11 Brugia-Knokke (Belgia).

Słowa kluczowe: obligacje projektowe, publiczno-prywatne partnerstwo, finansowanie infrastruktury, Europejski Bank Inwestycyjny, wsparcie kredytowe 